\title{
Attitude towards Biology and Its Effects on Student's Achievement
}

\author{
Ahmad R. Nasr \\ School of Education, University of Isfahan \\ PO box 81746 73441, Isfahan, Azadi square, University of Isfahan, Iran \\ Tel: 0098-311-793-2538Ｅ-mail: arnasr@edu.ui.ac.ir
}

Asghar Soltani K. (Corresponding author)

Faculty of Literature and Humanity, School of Education, Shahid Bahonar University of Kerman, Iran

PO box 76169133, Shahid Bahonar University of Kerman, Afzalipour square, Kerman, Iran

Tel: 0098-913-209-3549Ｅ-mail: asghar.soltani.k@gmail.com

Received: April 25, 2011 Accepted: May 9, 2011 doi:10.5539/ijb.v3n4p100

\begin{abstract}
The main purpose of this study was to examine the relation between attitudes towards science in biology courses and students' biology achievement. A total of 185 grade 12 (age 17-18 years) students in Isfahan answered to a 30-item questionnaire provided by authors based on STAQ-R inventory. The results showed that among attitude towards science dimensions, only "biology is fun for me", have meaningful and positive relation with students' achievement in biology. Also there was no significant difference between girls and boys in attitude towards biology, although girls had better achievements in biology in comparison with boys.
\end{abstract}

Keywords: Attitudes towards science, Achievement in biology, Attitude towards biology, Biology education

\section{Introduction}

With global scientific and technological growth occurring rapidly, declining student interest in science courses and careers is a worldwide concern that has prompted science education reform efforts on an international scale. Since student attitudes toward science effect course and career choices, measuring the impact of reform efforts on student attitudes is important and will require measurement tools with robust psychometric properties (Owen et al, 2008). Attitudinal studies in science education area are mostly pertinent to elementary, middle and high school students', and in some cases college students' attitudes towards science (Turkmen, 2007). As science has become ever more deeply embedded in our everyday life, how ordinary people perceive science has attracted growing attention not only from the scientific community, but also from social scientists (Bak, 2001). A significant amount of research in science education is devoted to understanding ways we can improve the quality of science education and increase enrolment in science courses and degrees. One of the key factors in learning science is students' attitudes and the development of positive attitudes toward science can motivate student interest in science education and science-related careers (George, 2006).

However definition or concept of attitude towards science is vague and ambiguous, but attitude is concept that defines emotional trends in response to affaires, persons, locations, events or ideas Therefore phrases as "I like science" or "I enjoy science courses" enumerate as attitude(Simpson and Oliver, 1990).

There are many factors that influence attitudes and achievement among adolescents. Some of the factors are associated with parental background and family environment. Other factors relate to individual characteristics such as self-concept, locus of control, and achievement motivation. Still other variables are associated with schools influences such as class climate, teachers, and administrative styles (Talton and Simpson, 1985). According to Osborne et al (2003), Studies have incorporated a range of components in their measures of attitudes to science including: the perception of the science teacher; anxiety toward science; the value of science; self-esteem at science; motivation towards science; enjoyment of science; attitudes of peers and friends towards science; attitudes of parents towards science; the nature of the classroom environment; achievement in science; and fear of failure on course. 
As Osborne et al (2003) cited in their review, However, Gardner's research (1995) offered little support for any strong relationship between attitude and achievement, Schibeci (1984) draws a stronger link between the two, quoting studies that show a correlation of 0.3-0.5. However, he also cites studies that show no relationship. The current position is best articulated by Shrigley (1990), who argues that attitude and ability scores can be expected to correlate moderately. Likewise, the measures used in the TIMSS study, albeit somewhat unsophisticated, have found a consistent relationship between attitude and achievement (Beaton et al., 1996). Weinburgh's (1995) meta-analysis of the research suggests that there is only a moderate correlation between attitude towards science and achievement. Longitudinal study of Oliver and Simpson (1988) shows a strong relationship between the three affective variables - attitude towards science, motivation to achieve and the self-concept that the individual has of their own ability - and their achievement in science.

Though many of researches on attitude towards science have dealt with science in general, but there are some researches that examine this concept in specific science courses as physics or chemistry and so on. For example Krogh (2005) assessed secondary students attitude towards physics and also Howe and Durr (1982) and Bennett (2001), did some similar researches on chemistry. Regarding the importance of attitude towards science between adolescents, in this paper, attitudes of secondary students towards biology and its effects on student achievements in biology courses were examined.

Based on the theoretical background, the research questions of this study were:

1- Is there any relation between attitude towards biology and students' achievements in biology courses at following dimensions?

a. Motivating Biology Class;

b. Self-Directed Efforts;

c. Family Models;

d. Biology is Fun for Me;

e. Peer Models.

2- Is there any significant difference in students' attitude towards biology in terms of gender?

3- Is there any significant difference in students' biology achievement in terms of gender?

\section{Method}

A questionnaire containing 30- item was used for this research which was based on Simpson-Troost Attitude Questionnaire-revised (STAQ-R). STAQ-revised is a revised form of Simpson-Troost attitude questionnaire that was developed by Owen et al (2008) to assess adolescent commitment to and achievement in science. STAQ has 22 Likert items that examines attitude towards science but we added 8 items to it regarding cultural and ethical properties of our country Iran. This instrument has 5 dimensions that each one includes from 4 to 9 items (Table 1). These inventory subscales that evaluate attitudes towards biology in 12 grade secondary students are: motivating biology class; self-directed efforts; family models; biology is fun for me; and peer models. We added some demographic questions as gender and economical class and collect student's scores in biology from high schools from which students had been chosen.

After pilot implementation of instrument, reliability coefficient (cronbach'alpha) was 0.85 that showed questions have strong internal correlation. Then a total of 185 grade 12 students (age 17-18 years) from secondary students of Isfahan were chosen to participate in research who answered to 30-item questionnaire that assesses their attitudes towards biology. After inventory implementation, data were analyzed with the statistical software, SPSS version 16.00 .

\section{Results}

The study proposed to examine attitude towards biology in secondary students and its effects on students' achievements in biology courses. Analysis of results indicated no significant difference between attitude towards biology and students' achievements in biology courses $(\mathrm{p}<0.05, \mathrm{r}=0.12)$. Coefficient of determination showed that there is 0.014 between attitude towards biology and biology achievement (Table 2).

Correlation coefficient between "motivating biology class" and students' biology achievement was $0.025(\mathrm{p}<0.05)$. This coefficient between "self-directed efforts" and biology achievement was 0.091( $\mathrm{p}<0.05)$. Correlation coefficient between "family models" and biology achievement was $0.036(\mathrm{p}<0.05)$ and between "peer models" and biology achievement was $0.067(\mathrm{p}<0.05)$. But this coefficient between "biology is fun for me" and 
biology achievement was $0.304(\mathrm{p}<0.05)$, that showed among all of attitudes towards biology dimensions, only this dimension has positive and meaningful relation with students' biology achievements (Table 3).

Also regression analysis results of attitude dimensions and students' achievements in biology (Table 4) showed that there is a positive and significant relation between "biology is fun for me" and students' achievements.

To examine second question T-test for independent means was used. According to the results of this test, there is no significant difference between girls and boys on attitude towards biology $(\mathrm{p}<0.05)($ Table 5).

Also results of used independent $\mathrm{T}$-test indicated that girls have better achievements in biology comparing with boys $(\mathrm{p}<0.05)$ (Table 6$)$.

\section{Discussion}

One of the usages of attitude study instruments in science education is assaying students' attitude towards science at elementary and secondary levels. Attitude towards science affects course and career choices of students and it is important to examine its different aspects and reinforce weak aspects through designing different educational programs. Biology as an important branch of science plays a substantial role in attitude towards science.

This study examined relation between attitudes towards science in biology courses and students' biology achievement. However results of this study showed that there is no statically significant difference between attitude towards biology and students' biology achievements but among five dimensions of attitude towards biology only "biology is fun for me" has meaningful relation with students' achievements. It means that considering fun aspects in biology is an important issue in biology education. In other words, when students sense that biology courses and educational materials in biology make a fun atmosphere in class, school and home, their positive attitudes towards biology have increased and this results in better achievement in biology.

Sex is one of the important variables related towards pupils' attitude to science. Some researches have shown that there is no relation between gender and attitude towards science (Greenfield, 1997), and results of this research are consistent with these studies. However, numerous of research studies have shown that boys have a consistently more positive attitude to school science than girls, although this effect is stronger in physics than in biology and girls' attitudes to science are significantly less positive than boys (Osborne, et al., 2003). This study confirms these studies. Nonetheless results indicated that girls' achievements in biology are significantly better than boys that this is normal in terms of better achievements of Iranian girls.

The educational implementations of this study are that we should make biological curriculum fun for students. It may suggest that we implement fun materials, texts and instruction methods. We can also inform biology teachers in in-service educations that have further more emphasis on this aspect of attitude towards biology.

\section{References}

Bak, H. J. (2001). Education and public attitudes toward science: Implications for the "Deficit Model" of education and support for science and technology. Social Science Quarterly, 82: 779-795. http://dx.doi.org/10.1111/0038-4941.00059

Beaton A., Martin, M. O., Mullis, I., Gonzalez, E. J., Smith, T. A., \& Kelley, D. L. (1996). Science Achievement in the Middle School Years: IEA's Third International Mathematics and Science Study, Chestnut Hill, MA: Boston College.

Bennett, J. (2001). The development and use of an instrument to assess students' attitude to the study of chemistry. International Journal of Science Education, 26: 141-169.

Gardner, P. L. (1995). Measuring attitudes to science. Research in Science Education, 25: 283-289. http://dx.doi.org/10.1007/BF02357402

George, R. (2006). A cross-domain analysis of change in students' attitudes toward science and attitudes about the utility of science. International Journal of Science Education, 28: 571-589. http://dx.doi.org/10.1080/09500690500338755

Greenfield, T. A. (1997). Gender- and grade-level differences in science interest and participation. Science Education, 81: 259-276. http://dx.doi.org/ 10.1002/(SICI)1098-237X(199706)81:3<259:AID-SCE1>3.0.CO; 2-C

Krogh, L. B. (2005). Studying students' attitudes towards science from a cultural perspective but with a quantitative methodology: Border crossing into the physics classroom. International Journal of Science Education, 27: 281-302. http://dx.doi.org/ 10.1080/09500690412331314469 
Oliver, J. S., \& Simpson, R. D. (1988). Influences of attitude toward science, achievement motivation, and science self concept on achievement in science: A longitudinal study. Science Education, 72: 143-155. http://dx.doi.org/10.1002/sce.3730720204

Osborne, J., Simon, S., \& Collins, S. (2003). Attitudes towards science: a review of the literature and its implications. International Journal of Science Education, 25: 1049-1079. http://dx.doi.org/10.1080/0950069032000032199

Owen, S. V., Toepperwein, M., Lichtenstein, M. J., Blalock, C. L., Liu, Y., Pruski, L. A., \& Grimes, K. (2008). Finding pearls: Psychometric re-evaluation of the Simpson-Troost attitude questionnaire. Science Education, 92: 1076-1095. http://dx.doi.org/10.1002/sce.20296

Schibeci, R. A. (1984). Attitudes to science: an update. Studies in Science Education, 11: 26-59. http://dx.doi.org/10.1080/03057268408559913

Shrigley, R. L. (1990). Attitude and behaviour are correlates. Journal of Research in Science Teaching, 27: 97-113. http://dx.doi.org/ 1002/tea.3660270203

Simpson, R. D. \& Oliver, J. S. (1990). A summary of major influences on attitudes toward and achievement in science among adolescent students. Science Education, 74: 1-18. http://dx.doi.org/10.1002/sce.3730740102

Taltont, E. L. \& Simpson, R. D. (1985). Relationships between peer and individual attitudes toward science among adolescent students. Science Education, 69: 19-24. http://dx.doi.org/10.1002/sce.3730690103

Turkmen, L. (2007). The influence of elementary science teaching method courses on Turkish teachers college elementary education major students' attitudes towards science and science teaching. Journal of Baltic Science Education, 6: 66-77.

Weinburgh, M. (1995). Gender differences in student attitudes toward science: A meta-analysis of the literature from 1970 to 1991. Journal of Research in Science Teaching, 32: 387-398. http://dx.doi.org/10.1002/tea.3660320407

Table 1. Questionnaire subscales, number and sample of questions

\begin{tabular}{ccc}
\hline subscales & Number of questions & Sample of questions \\
\hline Motivating Biology Class & 9 & I consider our biology classroom attractive and comfortable \\
Self-Directed Efforts & 6 & I tray hard to do well in biology \\
Family Models & 5 & My family watches biology programs on TV \\
Biology is Fun for Me & 6 & I really like biology \\
Peer Models & 4 & My best friend likes biology \\
\hline
\end{tabular}

Table 2. Correlation coefficient between attitude and achievement

\begin{tabular}{cccc}
\hline Variable & $\mathrm{r}$ & $\mathrm{R}^{2}$ & Sig. \\
\hline Attitude and achievement & 0.12 & 0.014 & 0.08 \\
\hline
\end{tabular}

Table 3. Correlation coefficient between dimensions of attitude and achievement

\begin{tabular}{cccc}
\hline Variable & $\mathrm{r}$ & $\mathrm{R}^{2}$ & Sig. \\
\hline Motivating Biology Class & 0.025 & 0.0006 & 0.735 \\
Self-Directed Efforts & 0.091 & 0.0082 & 0.218 \\
Family Models & 0.036 & 0.0013 & 0.624 \\
Biology is Fun for Me & 0.304 & 0.09 & 0.000 \\
Peer Models & 0.067 & 0.0045 & 0.362 \\
\hline
\end{tabular}


Table 4. Regression analysis of attitude' dimensions and achievement

\begin{tabular}{cccc}
\hline Model & $\mathrm{t}$ & St. deviation & Sig. \\
\hline Total Mean & 9.851 & 1.242 & 0.000 \\
Peer Models & 0.089 & 0.040 & 0.929 \\
Biology is Fun for Me & 4.221 & 0.046 & 0.000 \\
Family Models & -0.986 & 0.050 & 0.325 \\
Self-Directed Efforts & -0.871 & 0.045 & 0.385 \\
Motivating Biology Class & 0.422 & 0.012 & 0.673 \\
\hline
\end{tabular}

Table 5. Results of T-test for independent means of attitude towards biology in terms of gender

\begin{tabular}{ccccccc}
\hline variable & sex & Mean & Std .deviation & df & t & Sig. \\
\hline Attitude towards biology & girl & 115.56 & 10.94 & & & \\
& boy & 110.98 & 22.32 & 184 & 1.72 & 0.08 \\
\hline
\end{tabular}

Table 6. Results of T-test for independent means of biology achievement in terms of gender

\begin{tabular}{ccccccc}
\hline & & Mean & Std. deviation & df & t & Sig. \\
\hline variable & sex & & & & & \\
\hline \multirow{2}{*}{ Attitude towards biology } & girl & 16.40 & 2.10 & 184 & 3.92 & 0.00 \\
& boy & 15.15 & 2.19 & & & \\
\hline
\end{tabular}

